\title{
Differences among Nonresident Tourists Making Consumptive and Nonconsumptive Uses of Alaskan Wildlife
}

\author{
DAVID J. SNEPENGER ${ }^{1}$ and R. TERRY BOWYER ${ }^{2}$
}

(Received 28 March 1989; accepted in revised form 27 February 1990)

\begin{abstract}
Tourism is an important sector of Alaska's economy; 23\% of 4202 parties of tourists vacationing in Alaska from October 1982 to September 1983 indicated they hunted or fished. Tourists making consumptive use (hunting or fishing) of wildlife differed significantly from other visitors. Those who hunted or fished: 1) were in larger groups that contained a higher proportion of males; 2) tended to be younger; 3) were more involved in planning their vacation as indicated by starting the planning for their trip earlier and using more sources of information; 4) spent longer in the state and camped more often; 5) were more likely to charter aircraft within Alaska; 6) rated their experience highly, but thought they received a lower value for monies spent; 7) expended fewer total funds on their vacation; and 8) were more likely to return to Alaska than their counterparts who neither hunted nor fished. Visitors who used wildlife consumptively provided funds directly to the state for the conservation of these species through the purchase of hunting and fishing licenses and the subsequent receipt by the state of federal funds via the Pittman-Robertson and Dingell-Johnson acts. No formal mechanism exists for nonconsumptive users to aid wildlife conservation even though some nonconsumptive uses of resources are detrimental to wildlife. Although wildlife and their habitats are an important attractor for tourists, too little attention is given to the long-term benefits from the tourism industry in assessing the economic value of resource development and use that affects wildlife.
\end{abstract}

Key words: Alaska, fishing, hunting, tourists, wildlife

RÉSUMÉ. Le tourisme représente un secteur important de l'économie alaskienne, et $23 \%$ des 4202 groupes de touristes qui ont passé des vacances en Alaska entre octobre 1982 et septembre 1983, ont indiqué qu'ils avaient chassé ou pêché. Les touristes qui consommaient le produit de leur chasse ou de leur pêche différaient sensiblement des autres visiteurs sur les points suivants: 1) ils formaient de plus grands groupes qui contenaient une plus grande proportion d'hommes; 2) leur moyenne d'âge était généralement plus basse; 3 ) ils s'impliquaient plus dans la planification de leurs vacances en commençant les préparatifs de leur voyage plus tôt par exemple et en utilisant plus de sources d'information; 4) ils passaient plus de temps en Alaska et campaient plus souvent; 5) ils avaient plus tendance à noliser un avion à l'intérieur de l'Alaska; 6) ils évaluaient leur expérience de façon très positive, mais pensaient qu'ils n'en avaient pas eu autant pour leur argent; 7) ils dépensaient moins d'argent au total durant leurs vacances et 8) ils étaient plus susceptibles de revenir en Alaska. Les visiteurs qui consommaient le produit de leur chasse et de leur pêche apportaient directement des fonds à l'État pour la conservation de ces espèces avec l'achat de leur permis de chasse et de pêche, ainsi qu'avec l'application des lois Pittman-Robertson et Dingell-Johnson concernant le versement subséquent de fonds de la part du gouvernement fédéral. Il n'existe à l'heure actuelle aucun mécanisme touchant les touristes ne consommant pas de poisson ni de gibier pour aider à la conservation de la faune, alors même que celle-ci est affectée de façon négative par l'utilisation de certaines ressources où n'intervient pas la consommation de poisson et de gibier. Bien que la faune et son habitat soient des éléments importants en ce qui concerne l'attrait pour les touristes, trop peu d'attention est accordée aux bénéfices à long terme provenant de l'industrie du tourisme lorsqu'on évalue la valeur économique du développement et l'utilisation des ressources qui touchent la faune.

Mots clés: Alaska, pêche, chasse, touristes, faune

Traduit pour le journal par Nésida Loyer.

\section{INTRODUCTION}

Considerable information exists on the ethics, attitudes, and characteristics of those who make consumptive use (hunting or fishing) of wildlife and those who do not (Klein, 1973; More, 1973; Tocher and Milne, 1974; Fazio and Belli, 1977; Peterle and Scott, 1977; Shaw, 1977; Kellert, 1978; Marsters, 1978; Shaw and King, 1980; Applegate, 1982; Lyons, 1982), including how satisfied they are with the outcome of such activities (Potter et al., 1973; Hendee, 1974; Decker et al., 1980; McCullough and Carmen, 1982). Moreover, the economic value of wildlife and how best to measure this parameter have received considerable attention (Pearse and Bowden, 1969; Weeden, 1969; Horvath, 1974; Hay and Charbonneau, 1978; Martin and Gum, 1978; Arthur and Wilson, 1979; Noonan and Zagata, 1982; Sorg and Loomis, 1985). Although studies on consumptive uses of wildlife have not excluded tourists, data specifically addressing the importance of wildlife to tourism, especially differences between tourists who make consumptive or nonconsumptive uses of this resource, are comparatively rare. Moreover, few data on tourism in the Arctic are available.

In 1983, tourism was the fourth most important sector of
Alaska's economy; about 646000 nonresident tourists visited Alaska (Alaska Department of Commerce and Economic Development, 1984). In-state sales to these tourists exceeded $\$ 550$ million. One major attractor for visitors to Alaska is its abundant wildlife. Indeed, the value of wildlife to Alaska's economy has been well documented (Buckley, 1957). Visitors to the state often encounter wildlife, whether or not that was the primary purpose of their vacation. For instance, $>30 \%$ of all nonresident tourists visited national parks or wilderness areas in 1983 (Alaska Department of Labor, 1984).

The tourism industry recognizes natural resources as the foundation for many activities in addition to hunting and fishing. Components of the tourism economy that relate to nonconsumptive uses of wildlife include transportation, accommodations, shopping, and other activities (McIntosh and Goeldner, 1986). Tourists visit Alaska primarily for its scenery and wildlife (Field et al., 1985). Hence, we believe the economic viability of Alaska's tourism industry rests largely on how natural resources are perceived, managed, and used. Additionally, planning for the wise management of wildlife resources necessitates better understanding of tourists, both those who hunt and fish and those who do not engage in these activities.

\footnotetext{
${ }^{1}$ College of Business, Montana State University, Boseman 59717, U.S.A.; formerly, School of Management, University of Alaska Fairbanks, Fairbanks, Alaska 99775, U.S.A.

${ }^{2}$ Institute of Arctic Biology, and Department of Biology and Wildlife, University of Alaska Fairbanks, Fairbanks, Alaska 99775-0180, U.S.A. (C) The Arctic Institute of North America
} 
We examined differences between nonresident tourists who made consumptive and nonconsumptive uses of wildlife (including fish) while vacationing in Alaska. Clawson and Knetsch's (1966) model of the vacation experience facilitated our comparison of behaviors and attitudes of these tourists; specifically, travel party composition, vacation planning, travel to and within the state, "vacation behavior," and evaluation of the vacation experience were compared. Further, we discuss relationships between the tourism industry and Alaska's wildlife resources.

\section{METHODS}

Data provided by the Alaska Division of Tourism were used to delineate differences between visitors who came to Alaska to hunt or fish (consumptive tourists) and those who did not participate in hunting and fishing (nonconsumptive tourists). Our analysis excludes those who traveled to Alaska for business purposes. We recognize that visitors who did not hunt or fish could be subdivided into numerous categories (Alaska Department of Labor, 1984); such was not the purpose of this study. The term "nonconsumptive user" to identify these individuals is used for simplicity and clarity. Further, we combined nonresidents who hunted and fished into a single category because the proportion of individuals that do both has increased (Snepenger and Ditton, 1985).

During the 1983 tourism year (October 1982-September 1983) groups of tourists $(n=4202)$ at multiple checkpoints throughout the state were sampled monthly using a selfadministered questionnaire (Table 1). People on selected airline flights were sampled in Anchorage, Fairbanks, and Juneau. Those traveling in automobiles were sampled at border crossings near Haines, Skagway, Beaver Creek, and Dawson. Those traveling aboard cruise ships or ferries were sampled on board ship or at their last Alaskan port of call. Each group of tourists traveling together and sharing expenses was asked to complete a single questionnaire. Thus, the "traveling party" was the sampling unit for our analyses.

Data were analyzed using a VAX 8800 computer and SPSS Statistical Package at the University of Alaska Fairbanks. Variables were evaluated for skewedness and kurtosis and the most appropriate inferential statistic applied. Statistics used in this paper included the Mann-Whitney $U$-test and Chisquare test of independence (Siegel, 1956).

TABLE 1. Descriptions and measures of variables used to characterize travel parties of Alaskan tourists making consumptive or nonconsumptive uses of Alaska wildlife extracted from a self-administered questionnaire (variables are organized by Clawson and Knetsch's [1966] model for the vacation experience)

\begin{tabular}{ll}
\hline \hline Segment descriptions & Variables \\
\hline A. Travel party variables & 1. Group gender \\
& 2. Group size \\
3. Average age index
\end{tabular}

Measurements

Percentage males in travel party

Number of individuals in travel party

under 18 scored 1

18-24 scored 2

25-34 scored 3

$35-44$ scored 4

45-54 scored 5

55-64 scored 6

65 and over scored 7

Age categories were summed and divided by group size to get a measure of average group age
B. Vacation planning variables

1. Weeks planned

2. Information search index
Number of weeks before the trip planning occurred

Total number of the following information sources used in planning vacation:

A. saw an advertisement

B. friends/relatives

C. travel agent

D. Alaskan Division of Tourism Information

E. Prior visit

F. Convention \& Visitor Bureaus

G. Chambers of Commerce

H. Airlines

I. Tour/brochures/guide books
C. Travel to variables

D. Trip variables
1. Commercial airline

2. Cruise ship

3. Auto or camper

1. Monetary expenditures

2. Leisure activities index
Travel to Alaska on a commercial airline, yes or no

Travel to Alaska on a cruise ship, yes or no

Travel to Alaska in an automobile or camper, yes or no

Total monetary expenditures in dollars

Number of the following leisure activities engaged in by travel party: sightseeing, visiting friends/relatives, taking short education course, hunting, camping/hiking, visiting museums, attending concerts and performing arts, sport fishing, skiing, snowmobiling, other winter sports, small pleasure boating, learning about different cultures, visiting national parks and monuments

Rated overall vacation on a 5-point Likert scale from poor (1) to excellent (5)

E. Evaluation 1. Rate vacation

2. Value of trip

3. Visit again
Rated the value received on money spent on the trip from poor value (1) to excellent value (5)

Plan on visiting Alaska again - 5-point scale from definitely not (1) to will (5) 


\section{RESULTS}

Of $\mathbf{4 2 0 2}$ groups of nonresident tourists, $23 \%$ indicated they fished or hunted while vacationing in Alaska. Vacationing parties consumptively using wildlife were significantly more likely to have a larger proportion of males, be younger, and travel in larger groups than their nonconsumptive counterparts (Table 2).

Tourists making consumptive uses of wildlife devoted more effort to planning their vacations. They began planning their trip earlier and used more sources of information (Table 2).

Use of commercial airlines in travel to Alaska did not differ significantly between tourists who fished and hunted and those who did not (Table 2). Not surprisingly, once within Alaska those engaged in hunting and fishing activities were significantly more likely to charter aircraft (Table 2).

Although hunters and anglers spent over $\$ 2500$ per travel party, this sum was significantly less than for other visitors. Nevertheless, those who fished or hunted spent $68 \%$ more days within the state, which differed significantly from the other tourists. As expected, those making consumptive use of wildlife also spent significantly more nights camping (Table 2).

The categories of tourists did not differ significantly in rating the quality of their vacation experience; both rated the trip highly (Table 2). Although those who did not fish or hunt believed they had received a higher value for monies spent, they indicated that they were less likely to return to Alaska than their counterparts (Table 2).

\section{DISCUSSION}

Tourism in Alaska is a rapidly growing industry; visitors to the state have increased by $>230000$ from 1977 to 1985 .

TABLE 2. Behavioral and attitudinal characteristics of nonresident tourists who hunted or fished and those who did not while vacationing in Alaska, October 1982-September 1983

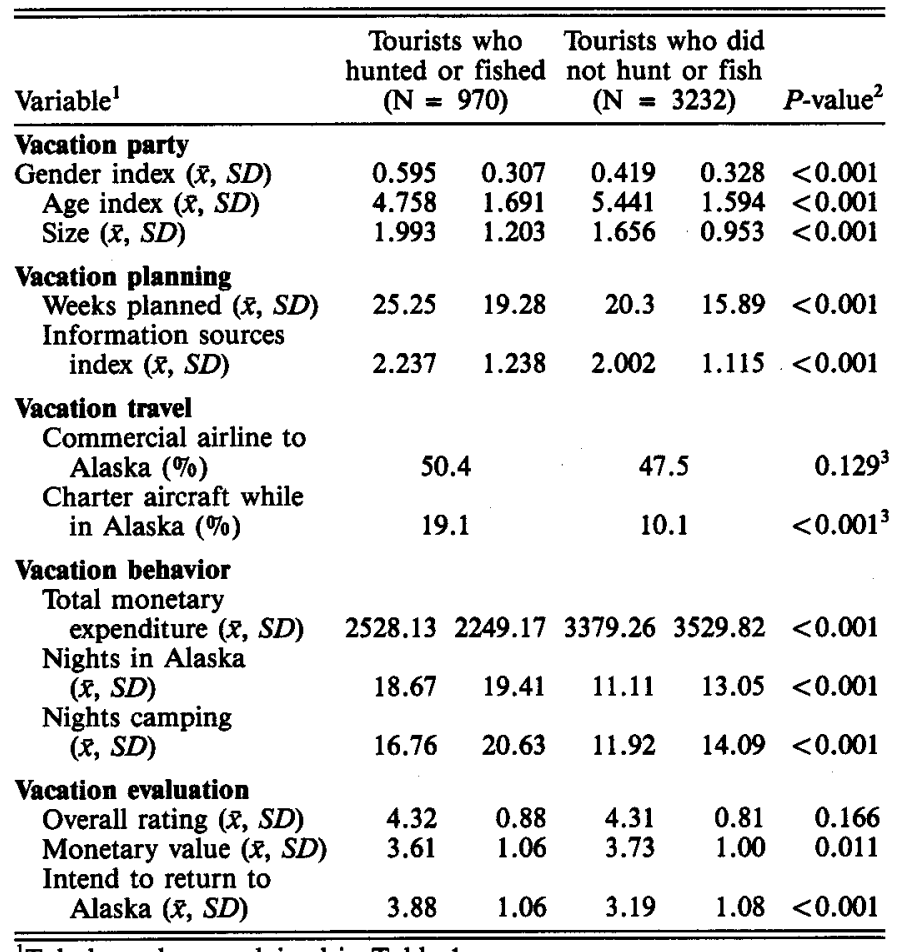

${ }^{1}$ Tabular values explained in Table 1 .

${ }^{2} P$-values are for the two-tailed Mann-Whitney $U$-test unless otherwise noted.

${ }^{3} P$-value is for the Chi-square test of independence.
Likewise, in-state sales to visitors have risen $>\$ 460$ million in the same 9-year period (Alaska Department of Commerce and Economic Development, 1984). Tourism is currently the third most important sector of Alaska's economy. Nonetheless, we believe the importance of wildlife to the tourism industry and how tourists perceive and use wildlife and their habitats in Alaska are not fully appreciated. A first step in this process is to characterize tourists making different uses of wildlife resources.

Clear differences exist between tourists who consumptively use wildlife and others vacationing in Alaska. Although those who fished and hunted spent less on their trips, we suspect their expenditures within the state may have equaled or exceeded those of other tourists. Those who hunted and fished were six times less likely than others to visit the state as part of an organized tour package (Snepenger, 1987). Monies spent for tour packages tend to stay within the state from which the tour originates and therefore are less likely to circulate within Alaska. Moreover, monies spent on tour packages often constitute a large percentage of total vacation expenditures. In contrast, use of chartered aircraft and purchase of camping supplies and services stimulate local economies, especially those in rural areas. Further, those who hunted or fished occurred in larger parties and were more likely to return to the state, thereby providing additional economic stimulus.

Because more sources were consulted by consumptive users when planning their trips, promotional efforts to target tourists desiring to hunt and fish should consider greater use of multiple information outlets such as travel agents and guide books in addition to hunting and fishing magazines. Women are participating more in consumptive uses of wildlife (Snepenger and Ditton, 1985); data on gender composition of the travel parties in this study also indicate women were included in groups that hunted and fished (Table 2). Consequently, advertising directed at those who hunt and fish should consider women.

Direct expenditures on nonresident hunting and fishing licenses and subsequent receipt of federal Pittman-Robertson (P-R) and Dingell-Johnson (D-J) funds by the state are other ways consumptive users help benefit Alaskan wildlife. Clearly, the consumptive use of Alaska's wildlife requires continued management to avoid overexploitation, but consumptive users provide direct support to aid in this process.

Adverse effects also may result from nonconsumptive uses of wildlife and critical habitat. In a review of the literature, Boyle and Samson (1985) reported negative effects on wildlife from a variety of nonconsumptive activities, including hiking and camping, boating, wildlife observation and photography, off-road vehicles, snowmobiles, spelunking, swimming and shore recreation, and rock climbing. Such impacts from tourism also will increase in Alaska as the visitor industry grows. Indeed, Denali National Park and Preserve already has closed much of its road system to private vehicles to help minimize disturbance to wildlife. No formal mechanism exists, however, for nonconsumptive users to provide direct funds to benefit wildlife.

Lautenschlager and Bowyer (1985) noted that wildlife was of value to both consumptive and nonconsumptive users of natural resources. Not only do those engaging in hunting or fishing benefit from the wise management of natural resources, but so do nonconsumptive users of wildlife, as well as those directly involved in the tourism industry. 
Nevertheless, the value of wildlife and their habitats in attracting tourists may not be fully understood or appreciated by the tourism industry. Indeed, we know of no instance where tourism monies have been expended for wildlife management or research.

The perception of pristine wilderness and abundant wildlife is clearly an important lure for tourists. For example, a survey of cruise ship passengers showed that the principal motivation for participating in an Alaskan cruise was to view the scenery of the Inside Passage and its wildlife (Field et al., 1985). Exploitation or use of natural resources that leads to real or perceived degradation of wildlife and their habitats is likely to negatively affect the tourism industry. For instance, extensive placer mining in and around Birch Creek, near Fairbanks, threatens an important sport fishery for grayling (Thymallus arcticus) (Wagener and LaPerriere, 1985; Reynolds et al., 1989). Logging of substantial areas of oldgrowth forest in southeastern Alaska has reduced critical habitat for numerous species, including black-tailed deer (Odocoileus hemionus), brown bear (Ursus arctos), bald eagle (Haliaeetus leucocephalus), and several species of salmon (Oncorhynchus spp.) (Schoen et al., 1988). Proposed oil extraction from the Arctic National Wildlife Refuge holds the potential to negatively affect use of calving areas by the Porcupine Caribou (Rangifer tarandus) Herd (U.S. Fish and Wildlife Service, 1987). Large breeding colonies of marine birds on the Pribilof Islands in the southeastern Bering Sea are an important tourist attraction. Large commercial harvests of walleye pollock (Theragra chalcogramma), however, have coincided with declines of piscivorous seabirds, including murres (Uria spp.) and kittiwakes (Rissa spp.) (Springer and Byrd, 1988). In addition to influencing wildlife populations, some of these resource uses cause considerable visual changes to the landscape that are likely to negatively affect tourism.

Effects of the Exxon Valdez oil spill on wildlife in and adjacent to Prince William Sound have been substantial. Direct mortality from oil occurred among many species of seabirds and marine mammals, especially sea otters (Enhydra lutra) (D.G. Calkins, Coordinator of Oil Spill Studies, Alaska Department of Fish and Game, pers. comm. 1989). The State of Alaska allocated $>\$ 35$ million to deal with legal and scientific aspects of the spill through February 1990, and more funds probably will be required. (The state, however, may be reimbursed under the provisions of the Comprehensive Environmental Response Compensation Act.) Of funds allocated to the spill, nothing was earmarked specifically for tourism; the state has no plans to direct any special tourism advertising toward changing negative impressions about Alaska brought about by the oil spill (J.C. Wright, Marketing Coordinator, Alaska Tourism Marketing Council, pers. comm. 1989). Exxon Corporation, however, gave $\$ 4$ million for an emergency marketing campaign to the Alaska Visitor's Association (a nonprofit organization) for exactly this purpose (K.S. Cowart, Executive Director, Alaska Visitor's Association, pers. comm. 1989).

Resource development and use, especially on nonrenewable resources, hold the promise of short-term and sometimes localized benefits to Alaska's economy. We believe too little attention has been given to the long-term benefits of tourism in assessing the economic value of resource development that may affect wildlife in Alaska.

\section{ACKNOWLEDGEMENTS}

We thank the Alaska Division of Tourism for allowing us access to data used in this study. D.G. Calkins, K.S. Cowart, and J.C. Wright provided much useful information. We are indebted to D.R. Klein and W.G. Eastland for assistance in the preparation of this manuscript.

\section{REFERENCES}

ALASKA DEPARTMENT OF COMMERCE AND ECONOMIC DEVELOPMENT. 1984. Alaska economic and statistical review. Juneau: State of Alaska.

ALASKA DEPARTMENT OF LABOR. 1984. Alaska traveler survey and visitor industry analysis 1983 - Overview. Juneau: State of Alaska.

APPLEGATE, J.E. 1982. A change in the age-structure of new hunters in New Jersey. Journal of Wildlife Management 46:490-492.

ARTHUR, L.M., and WILSON, W.R. 1979. Assessing the demand for wildlife resources: a first step. Wildlife Society Bulletin 7:30-34.

BOYLE, S.A., and SAMSON, F.B. 1985. Effects of nonconsumptive recreation on wildlife: a review. Wildlife Society Bulletin 13:110-116.

BUCKLEY, J.L. 1957. Wildlife in the economy of Alaska. Biological Papers of the University of Alaska 1:1-33.

CLAWSON, M., and KNETSCH, J.L. 1966. Economics of outdoor recreation. Baltimore: Johns Hopkins.

DECKER, D., BROWN, T., and GUTIERREZ, R. 1980. Further insights into the multiple satisfaction approach for hunter management. Wildlife Society Bulletin 8:323-331.

FAZIO, J.R., and BELLI, L.A. 1977. Characteristics of nonconsumptive wildlife users in Idaho. Transactions of North American Wildlife and Natural Resources Conference 42:117-128.

FIELD, D.R., CLARK, R.N., and KOTH, B.A. 1985. Cruiseship travel in Alaska: A profile of passengers. Journal of Travel Research 24:2-8.

HAY, M.J., and CHARBONNEAU, J.J. 1978. Determinants of economic value of hunting and fishing. Transactions of North American Wildlife and Natural Resources Conference 43:391-403.

HENDEE, J.C. 1974. A multiple-satisfaction approach to game management. Wildlife Society Bulletin 2:104-113.

HORVATH, J.C. 1974. Economic survey of southeastern wildlife and wildlife oriented recreation. Transactions of North American Wildlife and Natural Resources Conference 39:187-194.

KELLERT, S.R. 1978. Attitudes and characteristics of hunters and antihunters. Transactions of North American Wildlife and Natural Resources Conference 43:412-423.

KLEIN, D.R. 1973. The ethics of hunting and the anti-hunter movement. Transactions of North American Wildlife and Natural Resources Conference 38:256-267.

LAUTENSCHLAGER, R.A., and BOWYER, R.T. 1985. Wildlife management by referendum: when professionals fail to communicate. Wildlife Society Bulletin 13:564-570.

LYONS, J.R. 1982. Nonconsumptive wildlife-associated recreation in the U.S.: identifying the other constituency. Transactions of North American Wildlife and Natural Resources Conference 47:677-685.

MARSTERS, A.D. 1978. Some characteristics of New York hunters. New York Fish and Game Journal 25:72-78.

MARTIN, W.E., and GUM, R.L. 1978. Economic value of hunting, fishing, and rural outdoor recreation. Wildlife Society Bulletin 6:3-7.

MCCULLOUGH, D.R., and CARMEN, W.J. 1982. Management goals for deer hunter satisfaction. Wildlife Society Bulletin 10:49-52.

MCINTOSH, R.W., and GOELDNER, C.R. 1986. Tourism: principles, practices, philosophies. New York: John Wiley. $564 \mathrm{p}$.

MORE, T.A. 1973. Attitudes of licensed Massachusetts hunters. Transactions of North American Wildlife and Natural Resources Conference 38:230-234.

NOONAN, P.F., and ZAGATA, M.D. 1982. Wildlife in the marketplace: using the profit motive to maintain wildlife habitat. Wildlife Society Bulletin 10:46-49.

PEARSE, P.H., and BOWDEN, G.K. 1969. Economic evaluation of recreation resources: problems and prospects. Transactions of North American Wildlife and Natural Resources Conference 38:230-234.

PETERLE, T.J., and SCOTT, J.E. 1977. Characteristics of some Ohio hunters and nonhunters. Journal of Wildlife Management 41:386-399.

POTTER, D.R., HENDEE, J.C., and CLARKE, R.N. 1973. Hunting satisfaction: game, guns, or nature? Transactions of North American Wildlife and Natural Resources Conference 38:220-229. 
REYNOLDS, J.B., SIMMONS, R.C., and BURKHOLDER, A.R. 1989. Effects of placer mining discharge on health and food of arctic grayling. Water Resources Bulletin 25:625-635.

SCHOEN, J.W., KIRCHHOFF, M.D., and HUGHES, J.H. 1988. Wildlife and old-growth forests in southeastern Alaska. Natural Areas Journal 8:138-145.

SHAW, W.W. 1977. A survey of hunting opponents. Wildlife Society Bulletin 5:19-24.

and KING, D.A. 1980. Wildlife management and nonhunting wildlife enthusiasts. Transactions of North American Wildlife and Natural Resources Conference 45:219-225.

SIEGEL, S. 1956. Nonparametric statistics for the behavioral sciences. New York: McGraw-Hill, 312 p.

SNEPENGER, D.J. 1987. Segmenting the vacation market by novelty seeking role. Journal of Travel Research 26(2):8-14.

and DITTON, R.B. 1985. A longitudinal analysis of nationwide hunting and fishing indicators: 1955-1980. Leisure Science 7:297-320.
SORG, C.F., and LOOMIS, J. 1985. An introduction to wildlife valuation techniques. Wildlife Society Bulletin 13:38-46.

SPRINGER, A.M., and BYRD, G.V. 1988. Seabird dependence on walleye pollock in the southeast Bering Sea. Proceedings of the International Symposium on the biology and management of walleye pollock 1:667-677.

TOCHER, R., and MILNE, R. 1974. A cross cultural comparison of attitudes toward wildife. Transactions of North American Wildlife and Natural Resources Conference 39:145-150.

U.S. FISH AND WILDLIFE SERVICE. 1987. Arctic National Wildlife Refuge, Alaska, Coastal Plain Resource Assessment. Washington, D.C.: U.S. Department of the Interior.

WAGENER, S.M., and LaPERRIERE, J.D. 1985. Effects of placer mining on the invertebrate communities of Interior Alaska streams. Freshwater Invertebrate Biology 4:208-214.

WEEDEN, R.B. 1969. Economic evaluation of recreation resources: problems and prospects - a reaction. Transactions of North American Wildlife and Natural Resources Conference 34:293-297. 